\title{
Analysis of Biochemical Changes in Cultivars of Black Gram, Green Gram and Pea against Powdery Mildew
}

\author{
'P. P. Waghmare and 'Sahera Nasreen \\ 'Department of Botany, Government Institute of Science, \\ Post Graduate and Research Centre, Aurangabad, (MS) India -431001 \\ Corresponding Author: pramodwaghmare950@gmail.com
}

\section{Manuscript Details}

Manuscript Submitted : 16/10/2018

Manuscript Revised : :20/04/2019

Manuscript Accepted : 30/04/2019

Manuscript Published : 15/05/2019

\section{$\underline{\text { Available On }}$}

https://plantaescientia.website/ojs

\section{Cite This Article As}

Waghmare P. P. \& Sahera Nasreen (2019). Analysis of biochemical changes in cultivars of Black gram, Green gram and Pea against powdery mildew, Pla. Sci. 2019; Vol. 2 Iss. 01: 05-10. DOI: https://doi.org/10.32439/ps.v2il.5-10

\section{Copyright}

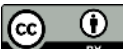

(c) The Author (s). 2019. Open Access This article is distributed under the terms of the Creative Commons Attribution 4.0 International License http://creativecommons.org/licenses/by/4.0/

Indexed In

Crossref, Index Copernicus International (ICI), Directory of Research Journal Indexing (DRJI), Scientific Indexing Services (SIS), CiteFactor,

\begin{abstract}
Powdery mildew disease of Black gram, Mung bean and Pea are major constraint in the production. The resistance of plants to various pathogens depends on synthesis and level of various defence enzymes like hydrolases; peroxidases and antimicrobial compounds like phytoalexins (Kuc, 1991 et al Kauffmann et al. 1987; Boiler, 1987; Mauch et al., 1988; Kale and Choudhary 2001, Koche and Choudhary, 2005). Present study focused on visual screening of selected crop cultivars against the powdery mildew and its biochemical correlation with chlorophyll content, sugars, phenols content, PR-Proteins and Phytoalexin activities. From the field studies, it was observed that, selected crop were found with powdery mildew incidence. This disease incidence data was correlated with biochemical changes and level of chlorophyll, sugars, phenols, PR-protein and Phytoalexin activities.
\end{abstract}

Keywords: Black gram, Green gram, Pea, Biochemical changes, Disease incidence, Powdery Mildew 


\section{INTRODUCTION}

Black gram (Vigna mungo (L.) Green gram (Vigna radiata (L.) Wilczek), Pea (Pisum sativum L.) and. All these selected pulse crops are important as a nutritional value and production point of view but biotic and abiotic diseases are major challenges to control. Minimize the disease incidence and severity. One of biotic disease is powdery mildew causing to Pigeon pea, Green gram, Black gram, Pea and chickpea by the many specialized races of fungal species in the genera Erysiphe, Microsphaera, Phyllactinia, Podosphaera and Uncinula. Powdery mildew of (Vigna mungo L.) Black gram Vigna radiata (L.) Wilczek (Green gram) and Pisum sativum L (Pea.) are caused by Erysiphe polygoni DC, and Erysiphe pisi are major diseases.

Infection of this disease can significantly reduce yield (by up to $25 \%$ ) by reducing photosynthetic leaf area also other biochemical changes in infected leaves compared to health and resistant to this diseases. Sanjay Guleria et al. (1997) reported post-infection decrease in chlorophyll a, chlorophyll total chlorophyll and reducing sugar content in the leaves of both resistant (DPP68 and JP71) and susceptible cultivars (Bonneville and Lincoln) of pea against powdery mildew (E. polygoni). Baka and Aldesuquy (1992) reported that decrease in reducing sugars in squash affected by powdery mildew caused by Spaerotheca fuliginea. Similarly Awad (2000) reported positive correlation between susceptibility to powdery mildew and leaf sugar content in most cucurbit varieties. Sindhan and Jaglan (1987) reported higher amounts of total phenols in resistant genotypes of groundnut affected by tikka leaf spot as compared to the susceptible ones. Avtar et al. (2003) observed higher levels of total phenols in resistant genotypes (NLM and HM 350) than susceptible (T8 and HM 65) fenugreek genotypes before and after the appearance of powdery mildew (E. polygoni) in artificially inoculated and natural environments.

Dinesh (2009) showed that initially healthy leaves of susceptible variety of Sunflower (Morden) had $1.204 \mathrm{mg} / \mathrm{g}$ of total phenols and it was increased to $3.980 \mathrm{mg} / \mathrm{g}$ after infection by E.cichoracearum. The synthesis of biochemical compounds and their level in plant offer a particular characteristic to it. Presence of various biochemical compounds in plant during its different developmental stages of indicates their importance for their survival. Production and level of plant hormones and some enzymes determine the percentage of germination, growth rate, development and reproduction (Abeles et al. 1971; Jones. 2001 and Dangl. 2001). The resistance of plants to various pathogens depends on synthesis and level of various defence enzymes like hydrolases; peroxidases and antimicrobial compounds like phytoalexins (Kuc, 1991 et al Kauffmann et al. 1987; Boiler, 1987; Mauch et al., 1988; Kale and Choudhary 2001, Koche and Choudhary, 2005). Thus all these reports suggest that the synthesis and level of biochemical compounds in plants play vital role in shaping various traits of all plant species. The objective of this research was to determine the roles of biochemical compounds, in the interaction of selected crops with powdery mildew fungi.

\section{MATERIAL AND METHODS}

\section{Germplasm Procurement and field experiment:}

Germplasm Procurement and field experiment: The germplasm of Black gram, Green gram, pea, was procured from Dr. P. D. K. V. Akola and M. P. K. V. Rahuri (MS). Germplasm are used for further sowing infield and in vitro experimentation.in vitro experiment carried out at Department of Botany, Government Institute of science, Aurangabad.

\section{Disease incidence and Severity analysis}

In all experiments, disease incidence (percentage) and severity were assessed at 2-day intervals. Severity of symptoms on individual plants were rated on a scale from 0 4 according to the percentage of foliage with yellowing or necrosis in acropetal progression: $0=0 \%, 1=1-33 \%, 2=34-$ $66 \%, 3=67-100 \%, 4=$ dead plant. Incidence and severity data ( $0-4$ scale) within a pot were used to calculate a disease intensity index (DII) by the equation: DII $=[(\Sigma \mathrm{Si} x \mathrm{Ni}) / 4 \mathrm{x}$ $\mathrm{Nt}) \times 100]$

\section{Estimation of chlorophyll content}

About $100 \mathrm{mg}$ of healthy and infected leaf samples of mung bean, chickpea and pea were collected from the field. The chlorophyll was extracted in Dimethyl sulfoxide (DMSO) as described by Hiscos and Israelstan (1979). The leaf samples were placed in a test tube containing $7 \mathrm{ml}$ DMSO and incubated at room temperature for 24 hours. The extracted liquid was transferred to graduate test tubes and volume was made up to $10 \mathrm{ml}$ with DMSO, and the stock solution was diluted to 50 per cent with DMSO. About $3 \mathrm{ml}$ sample of chlorophyll extract was transferred to cuvette and OD values were read at 645 and $663 \mathrm{~nm}$ along with DMSO blank in the spectrophotometer. Chlorophyll content was calculated by formula (Arnon, 1949).Reducing sugars for the leaf samples were estimated by Nelson's modification of Somogyi's method (Nelson, 1944). Non-reducing sugars were hydrolyzed by using $1 \mathrm{ml} 1 \mathrm{~N} \mathrm{H} 2 \mathrm{SO} 4$ and then estimated as in case of reducing sugars to get the total sugars. Non-reducing sugars were calculated by subtracting the reducing sugars from that of total sugars. 


\section{Estimation of total phenols}

Estimation of total phenols in the plant samples was carried out following Folin-Ciocalteau reagent method.

Reagents: Folin - Ciocalteau reagent (FCR) - 1\% and Sodium carbonate $-2 \%$

Procedure: One ml of alcohol extract was taken in a test tube to which one $\mathrm{ml}$ of Folin-ciocalteau reagent was added followed by two ml of sodium carbonate solution. Then the tubes were shaken well and heated on boiling water bath for exactly one minute and cooled under running tap water. The blue solution was diluted to fifteen $\mathrm{ml}$ with water and its absorbance was read at $650 \mathrm{~nm}$ in spectrometer. The amount of phenols present was calculated with the help of a standard curve prepared from catechol.

\section{Extraction and PR-protein assay}

Chitinase and $\beta$-1,3-glucanase were extracted by homogenizing $\mathrm{lg}$ of frozen tissues in $1 \mathrm{ml}$ and ice-cold extraction buffer (0.1M Sodium citrate buffer, $\mathrm{pH} 5$ ), in prechilled mortar and pestle. The extract was centrifuged at $10,000 \mathrm{rpm}$ for $15 \mathrm{~min}$. $\mathrm{lml}$ of supernatant was taken in $1.5 \mathrm{ml}$ centrifuge tube and proteins were precipitated by adding ammonium sulphate to saturation. The precipitated protein were centrifuged at 10,000 rpm for $15 \mathrm{~min}$ and supernatant was discarded. The protein pallated resuspended in $\mathrm{lml}$ extraction buffer and used as enzyme source for glucanase and chitinase activity. The assay of $\beta-1,3$ glucanase was performed according to method given by Kauffmann et al., (1987). The assay mixture was prepared by mixing $0.48 \mathrm{ml}$ of OlM Sodium acetate buffer $(\mathrm{pH}, 5.2), 100 \mu \mathrm{l}$ of enzyme extract, and $200 \mu \mathrm{l}$ Laminarin (Sigma) solution. The mixture was incubated at $37 \mathrm{oC}$ for $3 \mathrm{hrs}$. Then, $0.5 \mathrm{ml}$ alkaline copper tartarate was added to it and mixture was heated at $100 \mathrm{oC}$, in the boiling water bath for $5 \mathrm{~min}$. The mixture was then cooled to room temperature and $0.5 \mathrm{ml}$ of arseno-molybdate reagent was added to it. After the development of blue colour, $3 \mathrm{ml}$ of distilled water was added to each sample and absorbance was recorded at $660 \mathrm{~nm}$ against the blank containing the enzyme extract and all other reagent except Laminarin. The chitinase activity was analyzed according to the method of Reissig et al., (1954) and Boller et al., (1983). The enzyme assay mixture contained $100 \mu$ l of sodium acetate buffer ( $\mathrm{pH} 4.5), 100 \mu \mathrm{l}$ Sodium azide solution, and $200 \mu \mathrm{l}$ colloidal chitin and $100 \mu \mathrm{l}$ enzyme extract. The volume of this enzyme extract was adjusted to $1 \mathrm{ml}$ by extraction buffer and incubated at 37oC for $3 \mathrm{hrs}$. Then 100 $\mu$ of Sodium borate buffer ( $\mathrm{pH} 9.1)$ was added to it and heated to $100 \mathrm{oC}$ in water bath for $3 \mathrm{~min}$. The mixture was then cooled in tap water and centrifuged at $1000 \mathrm{rpm}$ for 5 min. The clear supernatant was collected and to it $3 \mathrm{ml}$ of DMAB reagent was added. The mixture was then incubated for $20 \mathrm{~min}$ at $37 \mathrm{oC}$. The absorbance was recorded immediately at $585 \mathrm{~nm}$ against the blank containing all the reagents and enzyme except chitin.

\section{Phytoalexin analysis:}

In this investigation the accumulation of phytoalexin medicarpin, in response to natural infection by powdery mildew fungi, was analyzed, by high-performance liquid chromatography (HPLC) following the method adopted by Edward and Strange (1991). The phytoalexin was also analyzed in infected and healthy leaves as well as in seedlings of different cultivars. One gram of sample was extracted with $5 \mathrm{ml}$ of $80 \%$ methanol. The methanol extract was reduced to $1 / 4^{\text {th }}$ of initial volume, under vacuum and extracted $(3 \mathrm{x})$ with ethyl acetate. The pooled ethyl acetate extract was reduced to dryness and contents were dissolved in one-ml acetonitrile. The $20 \mu \mathrm{l}$ acetonitrile extract was injected for quantitative analysis. The samples were chromatographed on Shimadzu HPLC system with ODS $C_{18}$ (Spherosphere) column ( $4 \times 250$ size $)$ maintained at $35^{\circ} \mathrm{C}$ temperature. The flow rate of mobile phase ( $50 \%$ aqueous acetonitrile) was $1.5 \mathrm{ml} /$ minute. The medicarpin was detected at $290 \mathrm{~nm}$ using a PDA detector with retention time of 23 minutes. The retention time was determined by co-chromatography of standard obtained from Sigma

\section{RESULTS AND DISCUSSION}

The field experiment reveals that cultivar of black gram, BDU- 1 and TAU- 1 is showed $3 \%$ and $19 \%$ disease incidence against powdery mildew 50 days after germination respectively. BDU-1 is resistant and TAU-1 is susceptible to powdery mildew. In cultivar of Green gram LGG, K-85l and cultivars of Pea, JP- 71 and Arkel showed that 5\%,37\%, 2.7\% and $48 \%$ disease incidence respectively ( Table.1). On the basis disease incidence index showed that cultivar BDU-1, LGG and JP-7l is resistant against the powdery mildew and TAU-1, K-851 and Arkel is susceptible against the powdery mildew. The chlorophylls loss in resistant and susceptible cultivars of Black gram, Green gram and pea due to development of powdery mildew.

The quantity of Chl.a, Chl.b and total chlorophyll in healthy and infected leaves. In susceptible Cultivars of selected crops that is TAU-1, K-85l and Arkel, the Chl.a content in healthy leaves was $1.77,1.89$ and $1.23 \mathrm{mg} / \mathrm{g}$ respectively and it has been reduced in infected leaves by powdery mildew that estimate the Chl.a 1.2, 0.89 and $0.41 \mathrm{mg} / \mathrm{g}$ respectively and in resistant cultivars of selected crop that BDU-1, LGG and JP-71, the Chl.a estimated in healthy leavesl.89, 1.98 and 1.81 it has been reduced to $1.71,1.82$ and $1.63 \mathrm{mg} / \mathrm{g}$ after 
infection of powdery mildew. Chlorophyll $b$ and total chlorophyll content in healthy and infected leaves are same trends in resistant and susceptible cultivars leaves (Table 2). The amount total sugars, reducing and non-reducing sugars in both healthy and infected leaves of selected crops cultivar were estimated. The estimated data showed that highest total sugar content found in infected leaves compared to healthy also same trends for phenols content (Table.2).The accumulation of phytoalexin and PRproteins in infected and healthy leaves showed highest value in infected leaves of Resistant and susceptible cultivars than healthy leaves of resistant and susceptible one (table. $3 \& 4$ )

Chlorophyll, sugar, phenols, phytoalexin and PR-protein in-plant could be positively correlated with the disease incidence index in case of black gram, green gram and pea of powdery mildew pathosystem. The Similar correlation was reported by Cachinero et al. (2002) in three Chickpea cultivars. Koche and Choudhary (2005) also reported that the level of PR-protein in Mungbean cultivars could be positively correlated with its resistance status. In 2007, Badere et al., reported the positive correlation of phytoalexin accumulation and resistant status of seven mungbean cultivars. These findings are also supported by the reports of Koche and Choudhary (2011). Balerao and Kothekar (2013) have reported the positive correlation between resistance of crop with its biochemical content. Khandare (2015). The present study are in accordance with above reports and could be exploited further at molecular level for developing powdery mildew resistant selected crop cultivars.

\section{ACKNOWLEDGEMENT}

Authors wish to express their sense of gratitude towards Director, Govt. Institute of Science, Aurangabad and Head of Department of Botany for making available all the required research facilities and all-time support.

\section{REFERENCES}

Avtar, R. et al., (2003), Changes in phenolics and some oxidative enzymes in fenugreek leaves dueto powdery mildew infection. ActaPhytopathologica et Entomologica, Hungarica, 38(3/4): 237-244. https://doi.org/10.1556/aphyt.38.2003.3-4.3

Badere R. S, et al. (2007). Genestein amount in cotyledons and leaves of Vigna radiata (L) Wilczekcultivars and mutants are correlated with resistance to leaf spot caused by Cercospora canescence. J. Plant Biol.,34: 139145

Bary, H. G. and Thorpe, W. V. (1954), Analysis of phenolic compounds of interest in metabolism. Methods of chemical analysis, 1: 27-51 Cercospora canescence. JPlant Biol, 34: 139-145
Biju, C. N., (2003), Studies on powdery mildew of pea (Pisum sativum L.) caused by Erysiphepolygoni DC. M. Sc. (Agri.) Thesis, Univ. of April. Sci. Dharwad (India).

Boller T, (1987), Hydrolytic enzymes in plant disease resistance. In: Kosuge T, Nester EW, eds. Plant-Microbe Interactions: Molecular and Genetic Perspectives, Vol. 2. New York, NY: Macmillan, 385-413.

Bradford MM, (1976), A rapid and sensitive method for the quantitation of microgram quantities of protein utilizing the principle of protein-dye binding. Analytical Biochemistry, 72: 248-54. https://doi.org/10.1006/abio.1976.9999

Dhillon, W. S., Bindra, A. S. and Kapoor, S. P., (1992), some biochemical changes induced inPowdery mildew infected grapevine leaves. Pl. Dis, Res., 7(2): 248-250.

Dhutraj, D, N., et al, (2005), Survey of pigeon pea wilt and powdery mildew of mung bean in Marathwada region. Indian Phtopath,58(3): 352.

Gupta, V, R., (2001), Studies on powdery mildew of green gram, black gram and pea caused by Erysiphe polygoni DC. Ph. D., Thesis, Dr. P. D. K. V. Akola (India)

Hiscos, J. D. and Israelstan, G. F., (1979), A method for extraction of chlorophyll from leaf tissue Without maceration. Candian J. Bot., 57 : 13301334

Jaypal, R. and Mahadevan, A, 1968, Biochemical changes in banana leaves in response of leaf spot pathogen. Indian Phtopath.,2l : 43-48.

Kunkalikar, S., (1989), Studies on powdery mildew of green gram. M. Sc. (Agri.) Thesis, Univ Agril. Sci.,Dharwad.

Koche D. K, et al. (2011). A novel technique for early detection and quantification of biochemicals from dicot plants. Bioscience Discovery, 2 (1) $15-20$

Koche D. K and Choudhary A. D, (2005). Elicitor induced expression of $\beta-1-3$ glucanase andchitinase genes in Vigna radiata (L) Wilczek. Bionature, 25(1-2): 69-74

Nandrajan, N. and Nand Gupta. (2010), Resistant cultivars of different pulse crops in India, Electronic J.Pl. Bree. 1(4) : 1099-1106

Nelson, N., (1944), A photometric adaptation of Somogyi method for determination of glucose. J.Biolog. Chem., 153: 375-378

Parashar, R. D. and Sindhan, G. S., (1986), Biochemical changes in resistant and susceptible varieties of pea in relation to powdery mildew disease. Prog. Hortic., 18(1-2), 135-137

Rathi, A. S., Parashar, R. D. and Sindhan, G. S., (1998), Biochemical changes in pea leaves due to powdery mildew infection. J. Mycol. Plant Pathol.,28 : 330-333.

Sun, H.; Yang, J.; Lin, C.; Huang, X.; Xing, R. and Zhang, K.Q. (2006) Purification and properties of a $\beta-1,3-$ glucanase from Chaetomium sp. that is involved in myco-parasitism. Biotechnology Letters, 28:131-135. https://doi.org/10.1007/s10529-005-5132-0 
Table 1. Disease incidence and disease severity of powdery mildew in each two naturally grown cultivars Green Gram and Pea.

\begin{tabular}{|c|c|c|c|l|}
\hline $\begin{array}{c}\text { Crop } \\
\text { name }\end{array}$ & Cultivar & $\begin{array}{c}\text { Number } \\
\text { of plant } \\
\text { observed }\end{array}$ & $\begin{array}{c}\text { Disease } \\
\text { incidence } \\
(\%)\end{array}$ & $\begin{array}{l}\text { Resistant } \\
\text { Status }\end{array}$ \\
\hline Black & BDU-1 & 1028 & 3 & Resistant \\
\cline { 2 - 5 } Gram & TAU-1 & 856 & 19 & Susceptible \\
\hline Green & LGG & 986 & 5 & Resistant \\
\cline { 2 - 5 } Gram & K-85l & 587 & 37 & Susceptible \\
\hline Pea & JP-71 & 867 & 2.7 & Resistant \\
\cline { 2 - 5 } & Arkel & 953 & 48 & Susceptible \\
\hline
\end{tabular}

Note: The values are mean of triplicate analysis

Table 3 Medicarpin analysis in Healthy and infected leaves of naturally grown selected cultivars

\begin{tabular}{|c|c|c|c|c|c|}
\hline & \multicolumn{5}{|c|}{$\begin{array}{l}\text { Phytoalexin Medicarpin content } \\
(\mu \mathrm{g} / \mathrm{g}) \text { in leaves (days after germination). }\end{array}$} \\
\hline & Cultivar & & $\begin{array}{c}\text { After } \\
40 \\
\text { days }\end{array}$ & $\begin{array}{c}\text { After } \\
60 \\
\text { days }\end{array}$ & $\begin{array}{c}\text { After } \\
80 \\
\text { days }\end{array}$ \\
\hline \multirow{4}{*}{$\begin{array}{c}\text { Black } \\
\text { Gram } \\
\text { TAU- } \\
1\end{array}$} & \multirow{2}{*}{$\begin{array}{l}\text { TAU-1 } \\
(S)\end{array}$} & $\begin{array}{c}\text { Infected } \\
\text { Leaves }\end{array}$ & 56.12 & 68.25 & 51.01 \\
\hline & & $\begin{array}{c}\text { Healthy } \\
\text { leaves }\end{array}$ & 43.7 & 59.14 & 41.02 \\
\hline & \multirow[t]{2}{*}{$\begin{array}{l}\text { BDU-1 } \\
(\mathrm{R})\end{array}$} & $\begin{array}{c}\text { Infected } \\
\text { Leaves }\end{array}$ & 69.01 & 88.69 & 56.06 \\
\hline & & $\begin{array}{c}\text { Healthy } \\
\text { leaves }\end{array}$ & 58.23 & 71.28 & 53.15 \\
\hline
\end{tabular}

Note: the values are mean of triplicate analysis

Table 4 Glucanase \& Chitinase activity in healthy and infected leaves of naturally grown selected cultivars ( $\mu \mathrm{kats} / \mathrm{mg}$ protein) 80 days after germination

\begin{tabular}{|c|c|c|c|c|}
\hline Crop & \multicolumn{2}{|c|}{ Cultivars } & Chitinase & Glucanase \\
\hline \multirow{4}{*}{$\begin{array}{l}\text { Black } \\
\text { Gram }\end{array}$} & \multirow{2}{*}{$\begin{array}{l}\text { TAU- } \\
\text { l(S) }\end{array}$} & $\begin{array}{c}\text { Infected } \\
\text { Leaves }\end{array}$ & 09.92 & 08.25 \\
\hline & & $\begin{array}{c}\text { Healthy } \\
\text { leaves }\end{array}$ & 06.23 & 5.96 \\
\hline & \multirow{2}{*}{$\begin{array}{c}\text { BDU-1 } \\
\text { (R) }\end{array}$} & $\begin{array}{c}\text { Infected } \\
\text { Leaves }\end{array}$ & 32.23 & 17.10 \\
\hline & & $\begin{array}{c}\text { Healthy } \\
\text { leaves }\end{array}$ & 22.12 & 16.97 \\
\hline
\end{tabular}

Note: the values are mean of triplicate analysis

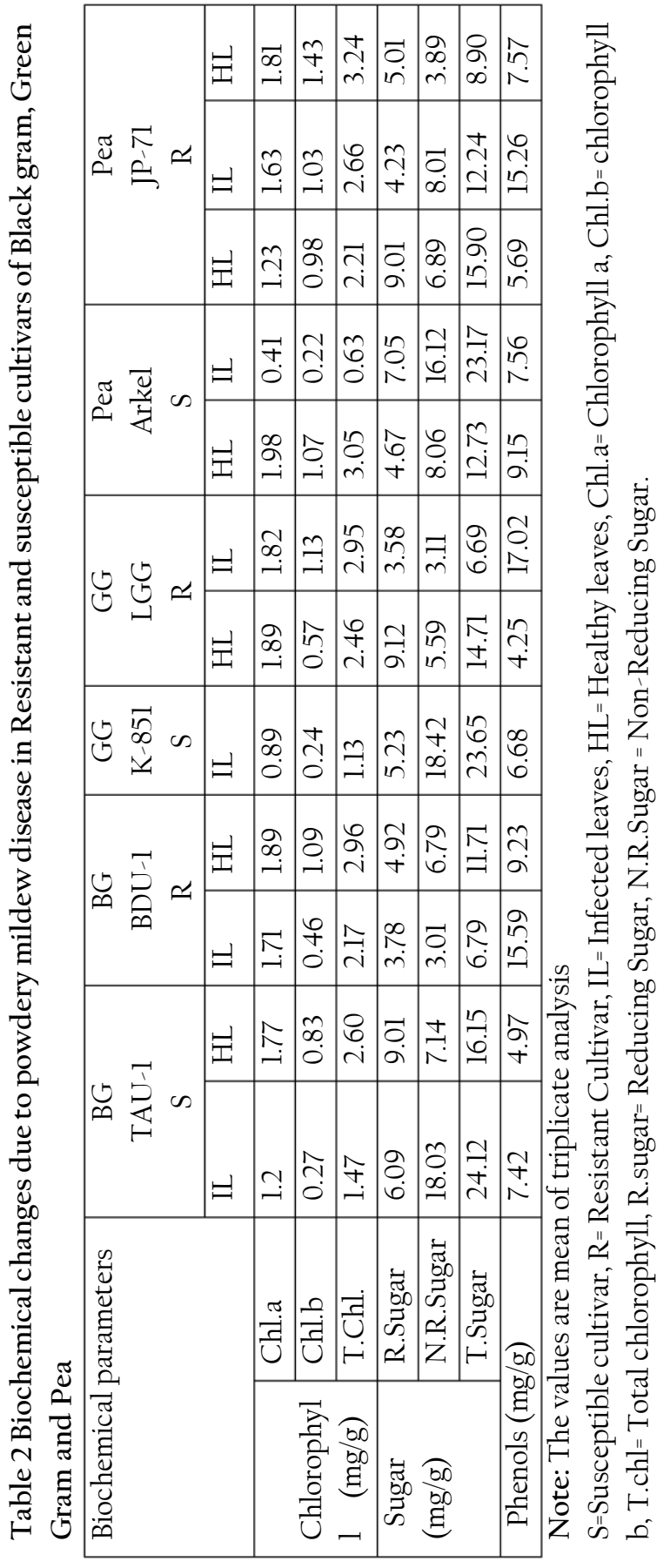



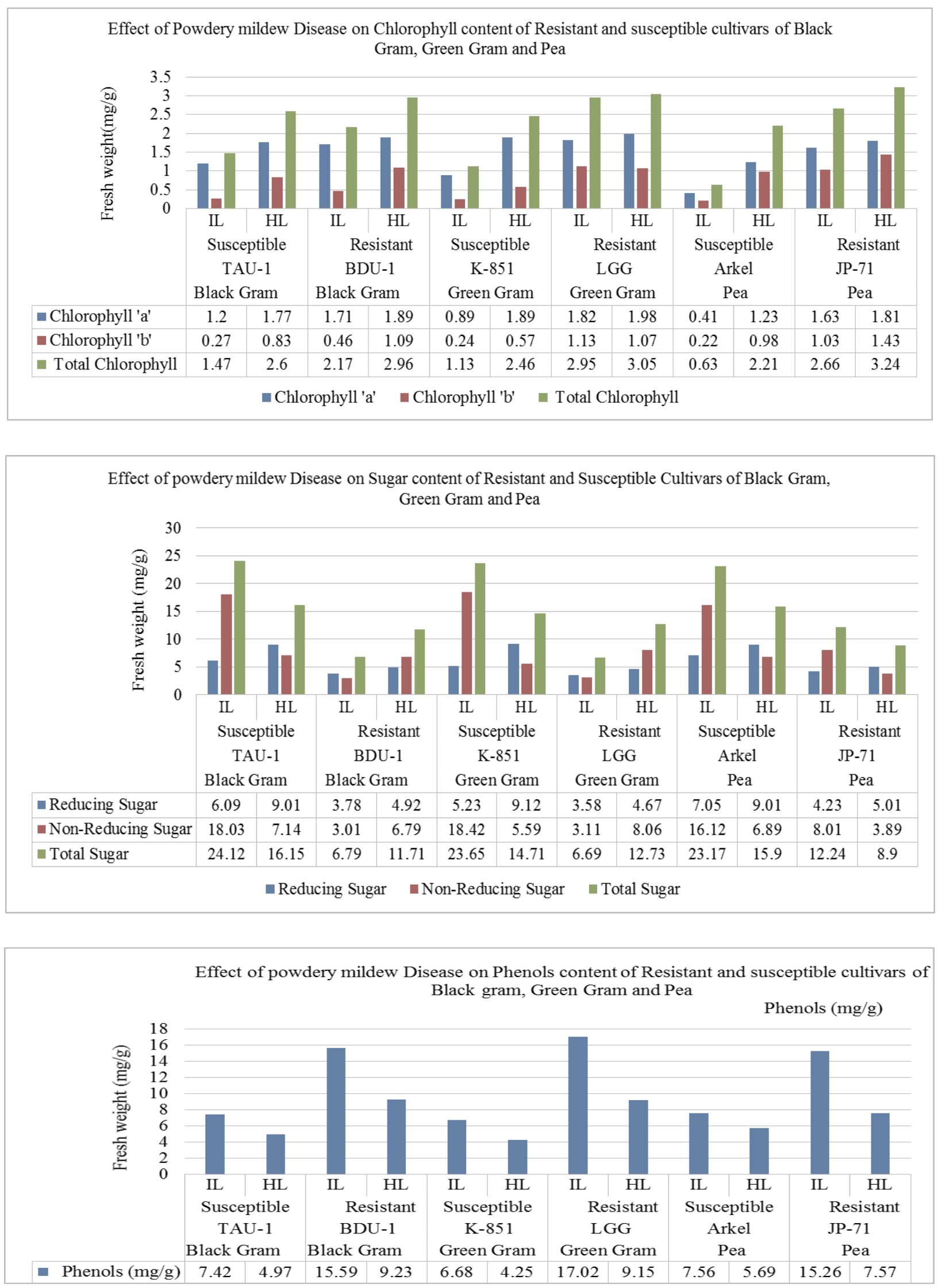

(c) 2019| Published by Plantae Scientia 